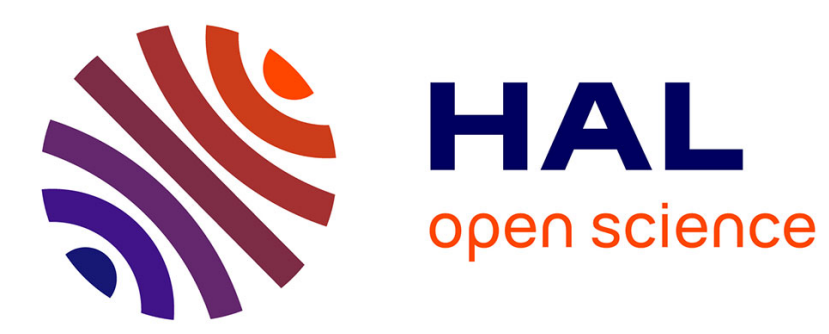

\title{
The ambivalent role of gender in redefining the German nation
}

\author{
Petra Rostock, Sabine Berghahn
}

\section{To cite this version:}

Petra Rostock, Sabine Berghahn. The ambivalent role of gender in redefining the German nation. Ethnicities, 2008, 8 (3), pp.345-364. 10.1177/1468796808092447 . hal-00571908

\section{HAL Id: hal-00571908 https://hal.science/hal-00571908}

Submitted on 1 Mar 2011

HAL is a multi-disciplinary open access archive for the deposit and dissemination of scientific research documents, whether they are published or not. The documents may come from teaching and research institutions in France or abroad, or from public or private research centers.
L'archive ouverte pluridisciplinaire HAL, est destinée au dépôt et à la diffusion de documents scientifiques de niveau recherche, publiés ou non, émanant des établissements d'enseignement et de recherche français ou étrangers, des laboratoires publics ou privés. 
Copyright @ SAGE Publications 2008 (Los Angeles, London, New Delhi and Signapore) 1468-7968

Vol 8(3): 345-364; 092447

DOI:10.1177/1468796808092447

http://etn.sagepub.com

\title{
The ambivalent role of gender in redefining the German nation
}

\section{PETRA ROSTOCK}

Free University of Berlin, Germany

\section{SABINE BERGHAHN}

Free University of Berlin, Germany

\begin{abstract}
Since the maxim of Germany as a non-immigration country was finally relinquished at the end of the $20^{\text {th }}$ century, the country has struggled with redefining itself as an immigration society and inventing a modified national identity. Our article argues that gender has come to play a pivotal role in this process of redefining a 'German' identity because it helps secure the 'self' by creating the Muslim/migrant 'other' as culturally different. Under the pretext of preventing women's rights violations, a renewed debate on integration and the duties of migrants is taking place. While we criticize the deployment of gender against the civic recognition of Muslims, violations of women's rights within minority groups do exist and must be combated. Our article offers some preliminary considerations as to how public agencies can intervene effectively against practices that are harmful to women, without in the process demonizing minority groups.
\end{abstract}

KEYWORDS gender equality $\bullet$ gender-specific violence $\bullet$ Germany $\bullet$ headscarf - migration • multiculturalism • Muslims

So-called honour crimes and forced marriages have recently become a major issue on the German political agenda. This is not to say, however, that such crimes had not taken place in Germany before. Forced marriages have existed in Germany at least since the first 'guest worker' generation came to the Federal Republic of Germany ${ }^{1}$ over 40 years ago. Although the up side of this public attention is a long-needed debate on the measures required to prevent such crimes, the sudden attention is not without problems. It has led to a generalization of individual cases even though no 
reliable figures on the problem exist: Islam and the entire Turkish or Muslim population are generally thought to oppress women.

This sudden interest in the rights of Muslim migrant women needs to be understood in a broader perspective. When the maxim of Germany as a non-immigration country was finally relinquished at the end of the 20th century, a new self-definition of the German nation had to be formulated. Gender has come to play a pivotal role in this process of redefining a 'German' identity. A renewed debate on integration and the duties of migrants is taking place under the pretext of preventing the violation of women's rights. At the same time, the social and economic problems of migrants are being ignored, and the shortfalls of German integration policy obscured. The perceived oppression of Muslim women, ostensibly proven by so-called honour crimes, forced marriages and the headscarf, serves to substantiate the idea that Islam in general and Muslims in particular are not (yet) part of German society. Gender equality serves as a marker of modern liberal German society even though it is far from being fully realized. Although government statements welcome Muslims in Germany and call Islam a part of Germany, reality offers a different picture. The fact that the demand for Islamic religious education, the introduction of 'Thoughts for Friday' 2 and the building of mosques have caused, and still cause, major debates in the public sphere and the media, shows that Germany is far from accepting Islam as part of its society.

To substantiate our thesis, we first set the context by outlining Germany's long road to becoming an immigration society, tracing the development of multiculturalism and describing the impact of an ethnically defined conception of citizenship. Subsequently, we discuss how the issue of gender equality is utilized to work against the civic recognition of Muslim migrants. Our critique of the current state of migration policies with regard to gender equality is completed by showing how the legal measures debated in relation to forced marriage or 'honour' crimes serve to restrict migration and create resentments against the Muslim minority. We close the article with a normative focus on initiatives from within the German-Turkish community, as well as from federal states, which attempt to intervene effectively against practices that are harmful to women, without in the process demonizing minority groups.

\section{THE LONG ROAD TO BECOMING AN IMMIGRATION SOCIETY}

With the formal acceptance that migrants were here to stay in Germany, there was a shift in perceptions of them. Migrants have always been referred to as 'foreigners', regardless of their citizenship, but Muslims and 
their religion are now at the centre of the current debate on Germany as an immigration society. Muslims are defined as a homogenous group, and the diversity of (former) migrants is also ignored. Simultaneously, the process of redefining Germany as an immigration society is accompanied by attempts of politicians of almost all persuasions to fill 'Germanness' with new content. As a result of the lessons learned from the National Socialist regime, 'German' is not referred to as an ethnic category. It is associated rather with secularity and gender equality, treated as general attributes of modern societies, and with a specific form of religion and religiosity and 'German value system' (deutsche Werteordnung) supposedly originating from Christian ethics. Although it is stated and even demanded that Islam must find its place within the German value system (cf. Schäuble, 2006), it remains unclear where this place could be - particularly, when there is no societal consensus as to what 'German values' are and what role the Christian religion should play. Do these values encompass the protection of human rights and fundamental freedoms (clearly not a unique German value), or identification with the German national soccer team, including enthusiastic waving of the German flag (something the German authors of this article, at least, certainly would not do)?

\section{A delegitimized nation}

The historical breaks in German history, the country's late unification in the 19th century and its 40-year-long division in the 20th century have all contributed to the difficulties in defining a national identity. Following the atrocities and defeat of the National Socialist regime, the nation's identity was deeply discredited. 'German' identity was then defined by distancing itself from the historically burdened national identity. Former government administrations in West Germany tried to define their national interests in a way that did not come into conflict with European interests, preferring multilateral policy. Undisputed support of European integration became the trademark of West Germany's foreign and European policy. The Federal Republic's state identity was thus fundamentally Europeanized, whereas the national identity was predominantly oriented towards Germany as a cultural nation (Beyme, 2004: 72; Schild, 2003: 32-3). Yet a shared and unique German culture seems to be a myth, as the presumption that Germany has more homogeneity of culture, religion and so forth than its neighbour states lacks plausibility (Elwert, 2001: 129).

Legally, the 'nation' has traditionally ${ }^{3}$ been defined in ethnic terms (by descent), a definition that is even determined by article 116 of the constitution (Elwert, 2001: 135). ${ }^{4}$ Until the introduction of the Nationality Act in 1993 and its reform in 2000, German citizenship was defined according to the Citizenship Law of 1913: in terms of ethnicity, passed on through blood lineage (jus sanguinis). Therefore, foreigners in Germany were not entitled 
to naturalization. They could apply for it only after having lived in Germany for a very long time, and the administrative decision was left to official discretion.

As Joppke (1999) rightly points out, the long-standing official maxim that Germany is 'not a country of immigration' was not so much a description of reality as a political-cultural norm grounded in the ethnocultural mode of West German nationhood:

While in principle delegitimized by its racist aberrations under the Nazi regime, ethnocultural nationhood was indirectly reinforced and prolonged by the outcome of World War II, with the division of Germany and the scattering of huge German diasporas in communist Eastern Europe and the Soviet Union.

Against this backdrop, the Federal Republic defined itself as a vicarious, incomplete nation-state, home for all Germans in the communist diaspora ...

[Therefore] it prioritized the immigration of co-ethnics ... Opening the national community to foreigners would have posed the risk of a redefinition of national identity, and of diluting the Federal Republic's historical obligation to its dispersed and repressed co-ethnics in the East (Joppke, 1999: 63).

Moreover, Turkish migrants' own uncertainty as to whether they would return 'home' and the political class's refusal for a long time to acknowledge that the 'guest workers' were there to stay made it possible to hold onto the perception of West Germany as an ethnically and culturally homogenous collective.

The idea of West Germany as a multicultural society was first introduced in 1980 in a symposium held by the Catholic and the Protestant churches. In preparation for the 'Week of the Foreign Citizen' ('Woche des ausländischen Mitbürgers'), the symposium issued a number of theses. One stated that 'In the federal republic we are living in a multicultural society' (Evangelische Kirche in Deutschland (EKD), 2007). At that time, the term was highly controversial. With its appeal for the recognition of ethnic and cultural minorities in West Germany and its demand for their juridical and political equality, ecumenical Christianity contradicted public and official opinion (Frank, 1995: 36). Although by the 1980s the migrant presence in the cities was inescapable, the permanence of immigration had not been recognized. Immigrants were still denied equal rights and citizenship. Instead, a range of short-term measures was introduced to improve the situation in schools and the social arena, for example by helping children to cope with their living situation in West Germany. At the same time, migrant children were prepared for eventual return to their parents' country of origin. In the long run, these measures did not lead to integration but rather to the reinforcement of social separation and a high degree of educational disadvantage for migrant children (Schierup et al., 2006: 147).

The public discourse at the time was characterized by fear of foreign infiltration and inundation, as West Germans 'discovered' the Turks as Muslims and constructed foreigners as 'others' with an insurmountably 
alien religion (Frank, 1995: 37). The image of the oppressed Turkish woman that has become so prominent in contemporary debate was at the time used only by West German feminists, who focused on the perceived victimization of migrant women and claimed superiority in knowing what is 'right' for the 'poor migrant woman' (Beck-Gernsheim, 2006). But this image was not yet taken up by policy makers. The discourse on multiculturalism in West Germany was divided into two irreconcilable positions: one embracing the cultural diversification of West Germany and willing to recognize migrants as members of society, the other rejecting foreigners in an attempt to preserve the notion of a homogenous West German society. ${ }^{5}$ Still, West German multiculturalism remained an intra-German affair in which ethnic immigrant groups were only marginally involved.

\section{Slow changes}

The 1980s debate on multiculturalism already reflects certain elements of the current redefinition of a 'German' identity through the construction of a (Muslim) migrant 'other'. Yet at that time, the maxim of West Germany as not an immigration country was still being upheld, while gender equality and the situation of migrant women were mainly issues within feminism and the women's movement. It was the unification of the two German states in 1990 and the end of Communism that made the definition of Germany as a delegitimized, incomplete nation-state obsolete, providing for a more relaxed attitude towards the German 'no-immigration' maxim (Joppke, 1999: 63).

In 1993, German citizenship law was reformed through the introduction of the Nationality Act. For the first time, a legal claim to naturalization was introduced, its precondition being 15 years of legal and permanent residence in Germany or just eight years for foreigners between the ages of 16 and 23. Hence, the jus sanguinis was supplemented with some elements of the jus soli. But when the government changed from the coalition of the Christian Democratic Union and the Liberal Party to the coalition of the Social Democratic Party and the Green Party in 1998, the no country of immigration tenet was finally given up officially. The new government heralded a decade of integration, and a new Nationality Act came into effect in 2000. Since then, foreigners with eight years of legal and permanent residence in Germany have been entitled to naturalization. Further preconditions are proof of sufficient knowledge of the German language, impunity, loyalty to the constitution and financial independence. Children of foreign parents are given German nationality (jus soli) if one parent has had legal and permanent residence in Germany for at least eight years and a permanent residence permit for at least three years. These children can also keep the nationality of their parents, but between the ages of 18 and 23 they must choose one nationality (Özcan, 2005). Nevertheless, there are 
a number of cases in which it is permissible to have one or more foreign nationalities in addition to German nationality (Die Beauftragte der Bundesregierung für Migration, Flüchtlinge und Integration, 2005: 44-5).

Although ethnic belonging is no longer the only way to gain individual access to citizenship, the German conception of citizenship insists on conformity to a set of values that is shared by all citizens, making cultural assimilation a precondition for naturalization (c.f. Koopmans et al., 2005). The prevalent view holds that integration should precede naturalization, meaning that migrants must demonstrate their 'Germanness' before they may acquire citizenship. It seems unrealistic, however, to expect integration into German society when citizenship and full participation in public and economic life are withheld (International Crisis Group and Laurence, 2007: i).

The new government also appointed an independent commission on immigration, which pointed out in its final report that Germany had been a country of immigration for many years and that immigrants were needed in Germany both for economic and for demographic reasons. ${ }^{6}$ The commission proposed a comprehensive integration policy requiring reforms and special measures in education, social welfare, the labour market and other areas (Schierup et al., 2006: 150). At this point, the situation of women played only a marginal role, with the commission merely affirming the need for protection of women from gender-specific persecution. In January 2005, the new Immigration Act came into effect, recognizing gender-specific persecution. ${ }^{7}$ Women's organizations voiced criticism over the fact that no women's associations participated in the legislative process. In particular, the German Women Lawyers Association argued that the selection criteria for the immigration of foreign employees would lead to the recruitment of mainly young, male migrants with a natural-scientific or technical training, while female migrants were viewed primarily either as family members or as unskilled workers for the low-wage sector (Diewell and Thomsen, 2002).

\section{A new 'Occidentalism'?}

The change in migration policy and the recognition of immigration as a political norm revealed a growing number of deficiencies concerning the integration of migrants, particularly with respect to equal opportunities in education and the job market. These shortcomings, along with the assassination of the provocative Dutch filmmaker Theo van Gogh in 2004, kindled a new debate on multiculturalism in Germany. ${ }^{8}$ The diagnosis issued by the media and politicians was that multiculturalism in Germany had failed even though it had never officially existed as a policy. Multiculturalism was used as a negative concept on which to blame any malfunction in the cohabitation of minority and majority societies. The results of previous German policy on foreigners - 'a kind of benevolent, paternalistic, and 
egalitarian (or pseudo-egalitarian) apartheid, an institutionalized separateness' (Brubaker, 2001: 538) - were blamed on the few 'multicultural idealists' who had been advocating in vain the recognition of migrants as members of German society.

As we have stressed, the official end of the no-immigration maxim and the now obsolete definition of Germany as a delegitimized, incomplete nation state, necessitated a new definition of 'German' identity. Unfortunately, this process has not so far brought about changes in the societal structure or the traditional self-perception as a homogenous society. Instead, arguments formerly brought forward to establish that Germany was not a country of immigration are now employed in the process of forming a new identity. The majority society seems to find the oriental and patriarchal 'other' necessary for its own self-definition, and uses it to preserve the fiction of a national homogeneity. The construction of homogeneity serves to fulfil several purposes at once, not least to obscure the obvious 'cultural' and political differences between East and West Germany. Gabriele Dietze, following Fernando Coronil (1996), defines this need for a (Muslim) 'other' in order to secure or reconstruct the 'self' as a new 'Occidentalism' (Dietze, 2004). These renewed expressions of 'Occidentality' can be most clearly observed in current debates on a 'deutsche Leitkultur' ('German leading or hegemonic culture') and the 'German value system'. These debates construct an insurmountable cultural difference between the Christian occidental 'us' and the Muslim 'other', a difference seen as manifesting itself both in the 'alien' religion of Islam and in the field of gender relations. Central to the debates on the integration of migrants and their religion into the German society is the social position of Muslim women. This is hardly a coincidence, as the gender relations of the 'other' have always served as the symbol for the backwardness and barbarism of the colonized (Castro Varela and Dhawan, 2006: 427-34). Therefore, while there has been some opening up in the ethnic definition of the German nation, the ultimate marker of difference between 'them' and 'us' still seems to be the question of gender equality.

\section{THE UTILIZATION OF GENDER AGAINST THE CIVIC RECOGNITION OF MUSLIMS}

The issue of gender equality works against the civic recognition of Muslims on at least two levels - in public discourse and in law. In accordance with the view of a 'Christian Occidental us' and a 'Muslim other', the predominant image of the foreign woman in public discourse is that of the oppressed Turkish or Muslim woman. Migrant women are typically represented as victims, either of German society or of Turkish men. They are seldom 
depicted as active agents, and when they are, this depiction is described as the exception to the rule. In addition, the oversimplified image of the poor oppressed Muslim woman is coloured by a claim of superiority on the part of German society in general (Beck-Gernsheim, 2006). The dangers of such essentializing views have been recognized at least partly in German gender and migration research, but positive, non-essentializing images of migrant women in the German public and media remain rare. One reason why gender equality seems to work so well against the civic recognition of Muslims is that the victimization of the 'other' woman serves as the screen through which the Christian European woman and society is distinguished as progressive and emancipated (Castro Varela and Dhawan, 2006: 427). Additionally, reports of violent acts such as 'honour' crimes, and the general perception of Islam as oppressive to women, stir up fears of falling back behind the already achieved status of gender equality.

\section{The headscarf debate}

With regard to gender equality, one indicator for the differentiation between a Christian-Occidental 'us' and a Muslim 'other' are the antiheadscarf laws passed by a number of federal states following the ruling of the Federal Constitutional Court in September 2003. ${ }^{9}$ The main argument put forward for prohibiting the headscarf but no other religious symbols is that the headscarf is not a religious but a political symbol for the oppression of women in Islam. Through this, the anti-headscarf laws prohibit teachers from displaying symbols and wearing clothes that express their adherence to a specific religion, ideological faith or political opinion that contravenes the duty of public servants to behave neutrally. Yet the laws include an exception clause for the display of Christian-Occidental values and traditions. Although the interpretations of this clause are not unanimous, the principal political aim is to tolerate Christian symbols, such as nuns teaching at public schools in their habit, while prohibiting the headscarf. Legislators have thus used the headscarf as an instrument of demarcation against the Muslim 'foreigners'.

In public discourse, the division between positions for and against the headscarf runs right through German society and even divides political parties, the Christian churches and the women's movement. But gender equality is always central to the line of argument: the headscarf is depicted either as a symbol of the oppression of women or a symbol enabling socalled neo-Muslims (Nökel, 2002; cf. also Karakaşoğlu, 2003; Klinkhammer, 2000) to emancipate themselves from their parents and participate in German society. The debate has created strange allies exactly because the headscarf enables various groups to instrumentalize gender against the civic recognition of Muslims. Conservative opponents of the headscarf and some feminists, such as Alice Schwarzer, Necla Kelek, Seyran Ateș and other 
authors with a Turkish migration background, cite the order to veil the female body or hair as evidence of the incompatibility of Islam with German values of democracy and freedom. Past and present oppression of and hostility towards women is ignored. In the context of growing antiIslamism, religious fundamentalism and continued violence against women, this position also ignores the complex intersections of racism and sexism. The paternalistic stance that positions Muslim women as oppressed victims may provoke a prioritization of struggles within migrant communities, with the allegedly more important fight against racism or anti-Islamism supplanting any challenge to gender violence (Castro Varela and Dhawan, 2006: 434). To wear a headscarf voluntarily ${ }^{10}$ does not mean that a woman promotes forced marriage, nor does it compellingly imply that women are subordinated to men, nor does it show why girls should not participate in sports, school trips or other activities. The simple denunciation of the headscarf as a symbol for the oppression of women is just one example of a growing tendency to deploy aspects of gender in order to 'prove' the anti-egalitarian, patriarchal orientation of Islam in general.

\section{Double standards}

When the circumstances are auspicious, even officials unenthusiastic about gender rights convert into firm believers and strugglers for the rights of women, and even homosexuals, revealing a remarkable capacity for double standards. As in the headscarf debate, this was again the case in the debate on naturalization tests in early 2006. These tests were directed only at specific migrants in Germany. Resettlers from eastern and southern Europe, facing socioeconomic difficulties similar to those of other migrants, do not have to take tests because they are considered ethnic Germans. Moreover, the tests alleged certain values (gender equality, acceptance of homosexuality) and knowledge (geography, history) as the German norm, in ways that are far from reflecting actual social consensus. When the federal state of Baden-Württemberg introduced, in January 2006, a 'values test' for Muslim migrants applying for German citizenship, to ensure that they shared the basic values of the Federal Republic, Muslim organizations and numerous politicians criticized the discriminatory nature of the test. The examination questioned migrants not only on their attitudes towards democracy and terrorism, but also the relationship between women and men, homosexuality, and so forth, posing questions such as: 'What do you think about the statement that a wife should obey her husband and that he is allowed to beat her if she is not obedient?' Or, to take another example: 'Imagine your adult son comes to you and explains that he is gay and that he wants to live together with another man. What is your reaction?'

Some weeks later, the Home Secretary of the federal state of Hesse decided to develop his own naturalization test under the slogan 'Knowledge 
and values'. This required profound knowledge of German history, the German political system, the European Union, and German art, music and literature, and again asked questions about the role of men and women in society. In acknowledgement of the critical reactions to the first test, the Hesse government emphasized that the examination was directed not only at Muslim migrants. But the test also posed highly gendered questions: 'A woman should not be allowed to go out in public or to travel without the company of a close male relative. What is your opinion of this statement?' The governments of both states are otherwise rather conservative with respect to the equality of men and women and the rights of homosexuals; their naturalization questionnaires therefore leave the distinct impression that gender equality is being employed opportunistically in order to demonize Muslim migrants and 'prove' their backwardness.

Women's rights seem to work as a highly effective means to mobilize emotions: not only do the 'poor oppressed Muslim women' need our help; 'we' also have to protect our modern gender and sexual politics. Instead of reflection on the very recent modernization of values and lifestyles that has taken place in Germany's majority population, there seems to be an implied symbolic order: 'we' have successfully overcome our own conservative gender model, and do not now want this reversed by 'backward' migrants. 'They' have to take their place at the end of the queue and must adapt to 'our' value system, even when this is more a myth than a reality. After discussions lasting months, the Home Secretaries of all German federal states agreed on joint criteria for naturalization, making a German language and a naturalization test binding. The standards are still to be worked out, but it has already been decided that topics will include the equality of men and women.

\section{The alien bride}

Even before the discussion on naturalization tests, Germany had found its authentic informant on patriarchal Turkish life in Germany. Shortly after an 'honour' killing of a young woman from a Kurdish family living in Germany had called public attention to the issue, Necla Kelek's book Die fremde Braut (The alien bride) was published (Kelek, 2005). As María do Mar Castro Varela and Nikita Dhawan (2006: 436) put it, in this moment a hegemonic listening, which only listens to what stabilizes the prevailing circumstances, amalgamated with the demand of politicized minorities for the right to their own, authentic voice.

In Die fremde Braut, Kelek, a sociologist born in Turkey who came to Germany with her family at the age of nine, first describes her family history and her own way to freedom and self-determination. The second part of the book is devoted to so-called import brides. Despite admitting that there are no reliable studies on the number of forced marriages in Germany, Kelek 
asserts that nearly every other marriage of Turkish migrants is either an arranged or a forced marriage, and that there is no difference between the two categories (2005: 214-25). She admits that there are 'different' Turks who have accepted German society and its rules as their own and have integrated themselves, yet maintains that these remain the exception to the rule, and that the majority of the two million plus people of Turkish origin have neither taken this road nor are willing to integrate (2005: 260 \& 262). While Kelek is certainly right to stress that any forced marriage is a human rights violation that must be punished, her book endorses prevailing notions of Turkish 'parallel societies' in Germany and of Islam as a barbaric religion and the root of all patriarchal evil. Because of its decontextualized representation of the Islam as barbaric and the enemy of Muslim women, Kelek's book received harsh criticism. Unfortunately, most of her critics have fallen into the same essentializing trap.

On 2 February 2006, the German weekly newspaper Die Zeit published a petition initiated by Yasemin Karakașoğlu and Mark Terkessidis. Signed by 60 migration researchers, the petition criticized the use of essays based on the personal experience of women such as Necla Kelek, Ayaan Hirsi Ali, Seyran Ates and others to enlighten the public and politicians about arranged and forced marriages and 'honour' crimes. A central target of their critique was the dissemination through Kelek's book of cheap clichés about 'Islam' and 'the Turks'. The researchers pointed out that forced marriages and 'honour' crimes do take place and must be combated with laws. In their analysis, however, crimes in the name of 'honour' are a political and not a moral problem and cannot be ascribed to Islam in opposition to western civilization. Because the phenomenon of migration comprises not only the Muslim minority, but also the everyday discrimination faced by both Muslim and non-Muslim migrants in the field of education, they called for a rational discussion about the future structure of the immigration society (Terkessidis and Karakașoğlu, 2006). Necla Kelek (2006) responded a week later that her critics had had the time, money and employees to analyse questions of forced and arranged marriages, 'honour' crimes and ethnic segregation, but had ignored these issues because they did not fit into their ideological concept of multiculturalism and because they did not want to see the human rights violations behind these issues.

These two letters triggered a heated media controversy (Butterwegge, 2006) in which the most sorely missing component was a representation of Muslims and Islam as complex, heterogeneous and diverse according to their own historical, regional, ethnic and class-specific contexts, as well as to the different experiences of migrants. The reaction of the petition's authors to accounts of gender violence within Muslim communities - routine belittlement and negation - was hardly expedient and no less essentializing. Moreover, in their critique, efforts to address sexist violence are subordinated under the allegedly more important struggle against racism. Almost 
none of the reactions to Kelek's book examined how images of oppressed Muslim women can be utilized to argue that the Muslims do not fit into German society because of their cultural 'otherness' (cf. Castro Varela and Dhawan, 2006).

Necla Kelek and a few other Turkish-German advocates of women's rights have been readily accepted by German officials as 'authentic' informants on the violations of women's rights occurring within the Turkish community. Their role is problematic because they reproduce the dominant discourse on the differences or incompatibility between an emancipated 'us' and a patriarchal 'Muslim other'. Their successful emancipation could be viewed as indicating the heterogeneity of the Turkish community in Germany; instead, they are seen as, and often depict themselves as, the exception to the rule. As a consequence, the stereotype of the 'oppressed Turkish woman' persists (Çelik, 2003). It becomes difficult for German Muslims to define for themselves what being 'Muslim' means (cf. Spielhaus, 2006). Moreover, the representation of Kelek and others as lone yet strong fighters against patriarchy within their own culture and religion obscures the fact that they can be seen as part of a larger movement against gender violence within minority groups.

The most striking aspect of the Kelek debate is that forced marriages and 'honour' crimes have long been identified and addressed by academic experts and women's rights organizations but have never gained the attention of the public or politicians. With the rise of the debate on the redefinition of 'German' identity, it seems as if the issue of gender-specific violence within Muslim communities has been exploited for the purpose of a restrictive integration regime. As described above, at the centre of the debate is the demand for the integration of migrants, which is justified by pointing to 'honour' crimes, forced marriage, a high rate of violence among migrants in general, and a tendency to separation and/or isolation. The Integration Summit and the Islam Summit, both initiated in 2006, as well as the amendment of the Immigration Act enacted in August 2007, suggest that it is more important to demand stricter rules for allegedly problematic groups than to discuss in detail how to combat violence while at the same time accepting migrants as Germans with full equal rights.

\section{Restricting migration in the name of women}

Up to now, most of the policy measures needed to combat gender-specific violence within minority groups in Germany have not been drawn up or passed. As part of the Integration Summit, and under the topic 'Improving the situation of women and girls, achieving gender equality', a working group coordinated by the Federal Ministry of Justice developed proposals on 'integration through law'. The group focused on protection from violence in the private sphere in general and from forced marriage in 
particular. In the summary of its work, the group highlighted the need for empirically sound findings, information on potential victims and perpetrators and publicity through awareness-raising campaigns, and advocated the establishment of specialized shelters for persons affected by violence. But these demands are far from new. Non-governmental organizations such as Terre des Femmes e.V., which has been working continuously on both forced marriage and crimes committed in the name of 'honour', have been and still are making the same demands (cf. Volz, 2003). But the public authorities at the lower levels of administration who most commonly deal with victims of violence still fail to protect minority women and men because of a lack of intercultural sensitivity, a lack of knowledge about these forms of violence, and even a lack of knowledge about possible legal and administrative aids. Often, youth welfare offices, and even courts, view violence in migrant families not as a social problem but as a private matter or a cultural problem. The internal structures of migrant families are likely to be seen as 'exterritorial' problems (Arpat, 1999: 61; Gedik, 2005: 321).

In the past, forced marriage was regarded as a criminal offence of coercion. In October 2004, the German parliament passed legislation making forced marriage a particularly severe case of the offence of coercion, punishable with up to five years' imprisonment (Bielefeldt, 2005: 24). Two years later, the Federal Council of Germany (Bundesrat) introduced a bill aimed at making forced marriage an element of an offence sui generis, in order to ostracize forced marriages socially and arouse an awareness of injustice, particularly among the relatives directly involved. Up to now, the bill has not been discussed in parliament. Human and women's rights experts question the efficacy of such laws: they do not anticipate many complaints on the part of the victims because that would mean opposing their own families, and in many cases this would be too momentous a step. What is really needed to combat forced marriage and other forms of gender-specific violence (within minority groups) is an elaborate policy strategy based on sound findings and composed of interlinked outreach, shelters, and a comprehensive education and sensitization of policy makers, responsible administrative agencies, teachers and police, as well as potential victims and their families. The experiences gained during the struggle of the second German women's movement against domestic violence teach us that the road to realizing the necessary measures is long. ${ }^{11}$ In the meantime, however, violations of women's rights are being employed to enforce new restrictions on immigration. In other words, on the level of law, too, gender is utilized to argue against the civic recognition of migrants.

Disguised as a measure to provide protection from forced marriage, the amendment to the Immigration Act establishes new hurdles to immigration. Among other regulations, the subsequent immigration of spouses is allowed only for partners who are at least 18 years old and who can demonstrate a basic knowledge of the German language. Spouses from the USA, Australia 
or Japan can still move to Germany without having to fulfill these criteria. Women's rights activists and experts have argued that the age and language restrictions do not constitute effective provisions: the basic requirement for subsequent immigration is the consummated marriage; thus, the law does not prevent forced marriages. Apart from the above-mentioned strategies, what would be needed in legal terms is an extended right to return for victims of marriage abduction and a right to residence independent from the spouse. But such open regulations concerning the right to residence are not likely to be introduced. In sum, up to now violence within minority groups has not been combated successfully, yet at the same time this violence has been exploited to create resentment against Muslims in Germany.

\section{A LONG ROAD AHEAD}

When forced marriages, 'honour' crimes or the headscarf are castigated as violations of universal human rights, a universalism is employed that becomes a rejection of the 'other', both in the form of denying many civil rights for migrants and of challenging an ethno-pluralistic understanding of the German nation. As we have pointed out, Germany is currently in the process of redefining 'German' identity, a process that started when the maxim that Germany is not an immigration country was finally abandoned. Characteristic of this redefinition process is the attempt to preserve the fiction of national homogeneity despite the realities of immigration and the obvious 'cultural' differences within German society. The ultimate marker between a Christian occidental 'us' and the (Muslim) 'other' remains the question of gender equality: gender proves to be a useful tool to secure the image of German society as modern and emancipated. At the same time, this progressive gender regime is depicted as being undermined by less emancipated migrants. While these lines of argumentation bear the risk of demonizing minority groups, drawing a clear line between an emancipated 'us' and a barbaric or at least backward 'other', the normative question that remains is how public agencies can intervene effectively against practices harmful to women, without in the process demonizing Muslim minorities. To close our article, we offer some preliminary considerations that require further development.

Contrary to what the exceptional status of Necla Kelek and others suggests, a number of migrant organizations have initiated activities against forced marriage and/or 'honour' crimes. Among the first was the secular Turkish Association of Berlin and Brandenburg (TBB), which issued a 10point plan calling for 'zero tolerance' towards violence against women and encouraged other Turkish and Islamic organizations to speak out against 
crimes committed in the name of 'honour'. ${ }^{12}$ The TBB identified the need to reinforce the funding of projects that offer targeted help to endangered women and provide awareness training, especially in schools. The latter need was partly taken up by a postcard campaign initiated by a social worker at the Berlin girl's club MaDonna. ${ }^{13}$ The girl's club had already created two postcards against forced marriage under the slogan 'Till death do us part'. ${ }^{14}$ Two German-Turkish boys in Berlin subsequently had themselves photographed for the campaign, under the slogan 'Honour is to fight for my sister's freedom'. ${ }^{15}$ Twenty thousand postcards were printed and circulated at the beginning of 2005. In the future, postcards will also be printed in Arabic and Turkish and distributed selectively in male domains such as cafés and sports clubs. A poster campaign with the same theme is being planned.

The MaDonna postcard campaign served as an inspiration for the visual component of a larger state campaign called 'her freedom - his honour'. The North Rhine-Westphalian Ministry of Integration started this campaign in November 2006, together with a surprisingly large alliance of migrant organizations and prominent women such as Alice Schwarzer and Seyran Ates, both of whom otherwise represent, as we have mentioned, a feminism with sometimes anti-Islamic overtones. ${ }^{16}$ The campaign comprises all the necessary aspects identified above. It aims not only to create publicity and awareness, but also to send a signal to women affected that there is help if they need it. Moreover, the campaign sets out to redefine terms such as 'honour', providing further education on the issue, and has developed an approach to combating forced marriage that is supplemented by an online consultancy. ${ }^{17}$ But perhaps even more important, the minister of integration of North Rhine-Westphalia, Armin Laschet - a Christian Democrat emphasized that this campaign is not about demarcating the majority from the minority society, but about focusing on shared values and cooperation. This initiative even includes the engagement of the Turkish newspaper Hürriyet, a popular paper with around 200,000 readers in Germany. This had earlier led a week-long campaign against German-Turkish authors such as Serap Cileli, Necla Kelek and Seyran Ateş because of their outspokenness against 'honour' crimes and forced marriage and their fight for women's rights. But in May 2005, the newspaper changed its position and expanded a campaign against family violence, started in Turkey, to Germany as well. This change of course is furthered by the recent 'honour' campaign.

The campaigns presented here demonstrate that public agencies can intervene effectively against practices harmful to women without demonizing minority groups. Moreover, the initiatives undermine many of the assumptions voiced in German public and politics about migrants, Muslims, gender and values. If ethnic minorities are to become truly part of German society, migration policy, and particularly the fight for the recognition of migrants and the prevention of gender-specific violence, needs to be 
formulated and implemented not as a special policy but as a regular part of social policy, aimed at limiting the risk of increased inequality and social disintegration for all (Bommes, 2007: 5). If initiatives continue to be understood as special policy, specific to minority groups, the symbolic charge will encourage one-sided blame for the failures of integration, exemplified in forced marriages and the like. This failure will be blamed on the refusal of migrants to integrate, or - even worse - on a general inaptitude of Muslim migrants because of their cultural 'otherness'. Any positive effects may be thwarted by an equivocal form of universalism that labels gender violence among migrants as cultural, while dismissing it in the majority society as individual. In this way, women's rights may continue to be used as a marker to distinguish 'them' from 'us', when what is really needed is to create diverse alliances to tackle oppressive forces of any kind.

\section{Acknowledgements}

We would like to thank Sarah Clasen, Avigail Eisenberg, Anne Phillips, Sawitri Saharso and Birgit Sauer for their helpful comments. An early version of this article was presented at the conference Gender Equality, Cultural Diversity: European Comparisons and Lessons, at the Free University Amsterdam in 2006 and we also thank participants for their feedback.

\section{Notes}

1 When we speak of 'Germany' we refer to the history of the Federal Republic of Germany. We do not analyse the migration policies of the German Democratic Republic.

2 'Thoughts for Friday' is analogous to 'Thoughts for Sunday', a five-minute-long broadcast every Saturday evening on public television in which Catholic priests and Protestant ministers express their views on Christian and theological questions. So far, 'Thoughts for Friday' is only published online.

3 'Traditionally' here refers to the view advanced by leading scholars and conservative politicians, as reflected in the laws. Before the unification of 1990, parts of the German Left in West Germany, in particular critical theorists, tried to define the German nation as a constitutional nation (Verfassungsnation).

4 Article 116 of the constitution, or Basic Law, defines as 'German' not only citizens but also refugees or expellees of German descent.

5 Cf. Dirke, 1994, and Frank, 1995, for a detailed history of German multiculturalism.

6 See Unabhängige Kommission 'Zuwanderung' (2001) for a summary of the report.

7 The act regulates three main areas: the immigration of foreign employees, the acceptance of refugees and the integration of new immigrants. Furthermore, questions concerning security and the fight against terrorism are included.

8 One explanation as to why the murder of Theo van Gogh in the Netherlands triggered a debate on multiculturalism in Germany is that, with it, the German 
public and officials came to the conclusion that Islam posed a threat not only in countries such as Iran, Saudi-Arabia, Afghanistan or Sudan but also in Europe.

9 So-called anti-headscarf laws, with an exception for Christian-Occidental values and traditions, have been passed in Baden-Württemberg, Bavaria, Hesse, Saarland and North Rhine-Westphalia.

10 How such a voluntary nature can be ascertained is still to be determined.

11 German legislation had been quite reluctant to combat domestic violence, viewing it as a private or cultural problem. It took over 20 years until, on 1 January 2002, legislation on protection against domestic violence (Gewaltschutzgesetz) was enacted.

12 The 10 points to fight intolerance towards violence against women are: (1) Zero tolerance towards violence against women; (2) no tolerance towards repressive attitudes on the pretext of religious or traditional reasons; (3) ostracism of values that discriminate against women; (4) public and active commitment of all Turkish and Islamic organizations to the right of women to self-determination; (5) promotion of discussions about equal rights for women within the Turkish and Islamic communities; (6) strict prosecution of forced marriages, and information campaigns on the subject within the Turkish and Islamic communities; (7) intercultural opening of educational facilities and promotion of the intercultural competence of teachers; (8) establishing of a professorship in Islamic theology at a Berlin university, introduction of Islamic religion as a subject at Berlin schools; (9) enforcement of the duty to attend school lessons in swimming, sports, biology and sexual education; (10) public presentation of the intrinsic values of Islam (cf. Türkischer Bund in Berlin-Brandenburg (2005).

13 For more information, cf. MaDonna Mädchenkult.Ur e.V. (n.d.).

14 In German: 'Bis das der Tod uns scheidet.'

15 In German: 'Ehre ist für die Freiheit meiner Schwester zu kämpfen!'

16 For more information, see Ministerium für Generationen, Familie, Frauen und Integration (n.d.).

17 See Mädchenhaus Bielefeld e.V. (n.d.).

\section{References}

Arpat, M. (1999) 'Gewalt in Immigrantenfamilien am Beispiel von Familien aus der Türkei und die kulturrelativistische Blindheit der deutschen Politik' (Violence in migrant families exemplified with families from Turkey and the cultural relativistic blindness of German politics), in B. Erbe (ed.) Frauen fordern ihr Recht: Menschenrechte aus feministischer Sicht (Women demand their right: human rights from a feminist viewpoint), pp. 58-63. Berlin/Hamburg: Argument.

Beck-Gernsheim, E. (2006) 'Türkische Bräute und die Migrationsdebatte in Deutschland' (Turkish brides and the migration debate in Germany), Aus Politik und Zeitgeschichte 1-2: 32-7.

Beyme, K. (2004) Das politische System der Bundesrepublik Deutschland (The political system of the Federal Republic of Germany). Wiesbaden: VS Verlag für Sozialwissenschaften.

Bielefeldt, H. (2005) 'Zwangsheirat und multikulturelle Gesellschaft - Anmerkungen zur aktuellen Debatte' (Forced marriage and multicultural society - 
comments on the current debate), German Institute for Human Rights, Essay No. 2, October [http://files.institut-fuer-menschenrechte.de/488/d43_v1_file_4381 a9bb19f6b_DIMR_Essay_2_Z_EinzelseitenRZ.pdf], 21 May 2006.

Bommes, M. (2007) 'Integration - gesellschaftliches Risiko und politisches Symbol' (Integration - societal risk and political symbol), Aus Politik und Zeitgeschichte 22-3: 3-5.

Brubaker, R. (2001) 'The return of assimilation? Changing perspectives on immigration and its sequels in France, Germany, and the United States', Ethnic and Racial Studies 24(4): 531-48.

Butterwegge, C. (2006) 'Kein journalistisches Ruhmesblatt' (No journalistic glorious chapter), Frankfurter Rundschau, 17 March, p. 7.

Castro Varela, M. and N. Dhawan (2006) 'Das Dilemma der Gerechtigkeit: Migration, Religion und Gender' (The dilemma of justice: migration, religion and gender), Argument 266: 427-40.

Çelik, S. (2003) 'Positionen türkischer Migrantinnen im Einwanderungsdiskurs' (Positions of Turkish migrant women in migration discourse), Beiträge zur Feministischen Theorie und Praxis 63-4: 29-39.

Coronil, F. (1996) 'Beyond Occidentalism: Toward Nonimperial Geohistorical Categories', Cultural Anthropology, 11(1): 51-87.

Die Beauftragte der Bundesregierung für Migration, Flüchtlinge und Integration (2005) 'Wie werde ich Deutsche/r?' (How can I become German?) [http:// www.einbuergerung.de/Einbuergerung_2006_neu.pdf], 6 September 2006.

Dietze, G. (2004) 'Kollektivkörper im Schüttelfrost' (Collective body shivering), Freitag 50: 16.

Diewell, M. and M. Thomsen (2002) 'Stellungnahme zum Entwurf eines Gesetzes zur Steuerung und Begrenzung der Zuwanderung und zur Regelung des Autenthaltes und der Integration von Unionsbürgern und Ausländern (Zuwanderungsgesetz) der Fraktionen SPD und Bündnis 90/DIE GRÜNEN (BT Drs. 14/7387 vom 8. November 2001)' (Statement on the draft of a law on the control and restriction of migration and the regulation of the residence and integration of Union citizens and aliens (Immigration Act) of the parliamentary factions of the Social Democratic Party and Alliance 90/The Green Party (Parliamentary printed matter no. 14/7387 from 8 November 2001)), Deutscher Juristinnenbund, January [http://www.djb.de/Kommissionen/kommission-oeffentliches-recht-europaund-voelkerrecht/st-02-02-EFraktionZuwanderungsG/], 23 March 2007.

Dirke, S. (1994) 'Multikulti: The German Debate on Multiculturalism', German Studies Review 17(3): 513-36.

Elwert, G. (2001) 'Deutsche Nation' (German nation), in B. Schäfers and W. Zapf (ed.) Handwörterbuch zur Gesellschaft Deutschlands (Dictionary of German society), pp. 127-37. Bonn: Bundeszentrale für politische Bildung.

Evangelische Kirche in Deutschland (EKD) (2007) 'Interkulturelle Woche: Die Geschichte' (Intercultural week: The history) [http://www.ekd.de/interkulturelle woche/343.html], 19 March 2007.

Frank, S. (1995) 'Schön bunt und nützlich. Der Diskurs über die multikulturelle Gesellschaft' (Very colourful and useful: The discourse on the multicultural society), Blätter des iz3w 205: 36-9 (Part I) and 206: 34-7 (Part II).

Gedik, I. (2005) 'Zwangsheirat bei Migrantenfamilien in der Bundesrepublik' (Forced marriage in migrant families in the Federal Republic), in V. Deile, 
F.-J. Hutter and S. Kurtenbach (ed.) Jahrbuch Menschenrechte: Schwerpunkt Frauenrechte (Yearbook human rights: focal theme women's rights), pp. 318-25. Frankfurt am Main: Suhrkamp.

Heitmeyer, W. (2007) 'Was hält die Gesellschaft zusammen? Problematische Antworten auf soziale Desintegration' (What is keeping society together? Problematic answers to social disintegration), in W. Heitmeyer (ed.) Deutsche Zustände: Folge 5 (German conditions: Episode 5), pp. 37-47. Frankfurt am Main: Suhrkamp.

International Crisis Group and J. Laurence (2007) 'Islam and Identity in Germany', Europe Report No. 181, March, Berlin/Brussels [http://jonathanlaurence.net/ ICG-JL-Report.pdf], 19 March 2007.

Joppke, C. (1999) Immigration and the Nation-State: The United States, Germany, and Great Britain. Oxford: Oxford University Press.

Karakaşoğlu, Y. (2003) “"Stellungnahme zu den Motiven von jungen Musliminnen in Deutschland für das Anlegen eines Kopftuches", Gutachten vorgelegt in dem Verfahren über die Verfassungsbeschwerde der Frau Ludin' ('Statement on the motives of young Muslim women in Germany to wear a headscarf', expert's report presented in the proceedings regarding the constitutional complaint of Mrs Ludin), August [http://www.wz-berlin.de/zkd/aki/files/karakasoglu_gutachten ch.pdf], 15 August 2006.

Kelek, N. (2005) Die fremde Braut. Ein Bericht aus dem Inneren des türkischen Lebens in Deutschland (The alien bride: Inside report on Turkish life in Germany). Köln: Kiepenheuer \& Witsch.

Kelek, N. (2006) 'Sie haben das Leid anderer zugelassen!' (You have permitted the distress of others!), Die ZEIT 7: 48.

Klinkhammer, G (2000) Moderne Formen islamischer Lebensführung: eine qualitativ-empirische Untersuchung zur Religiosität sunnitisch geprägter Türkinnen der zweiten Generation in Deutschland (Modern forms of Islamic conduct of life: A qualitative empirical study on the religiosity of second generation Sunni Turkish women in Germany). Marburg: Diagonal.

Koopmans, R., P. Statham, M. Guigni and F. Passy (2005) Contested Citizenship: Immigration and Cultural Diversity in Europe. Minneapolis, MN: University of Minnesota Press.

Mädchenhaus Bielefeld e.V. (n.d.) Nein zu Zwangsheirat (No to forced marriage) [http://www.zwangsheirat-nrw.de].

MaDonna Mädchenkult.Ur e.V. (n.d.) 'Veröffentlichungen' (Publications) [http:// www.madonnamaedchenpower.de/veroeff.htm].

Ministerium für Generationen, Familie, Frauen und Integration (n.d.) 'Ihre Freiheit - seine Ehre' (Her freedom - his honour) [http://www.ehre.nrw.de].

Nökel, S. (2002) Die Töchter der Gastarbeiter und der Islam: zur Soziologie alltagsweltlicher Anerkennungspolitiken; eine Fallstudie (The guest workers' daughters and the Islam: on the sociology of every day life recognition politics; a case study). Bielefeld: Transcript.

Özcan, V. (2005) Country Profile Germany, Focus Migration [http://www.focusmigration.de/typo3_upload/groups/3/focus_Migration_Publikationen/Laender profile/CP01_Germany.pdf], 1 August 2006.

Reimann, A. (2006) Kopftuch-Streit: Frauen werden zu Unruhestifterinnen stigmatisiert (Headscarf conflict: Women are stigmatized as troublemakers), Spiegel 
Online [http://www.spiegel.de/politik/deutschland/0,1518,424999,00.html], 6 July 2006.

Schäuble, W. (2006) 'Perspektiven für eine gemeinsame Zukunft' (Perspectives for a joint future), government declaration of the Minister of the Interior, Dr. Wolfgang Schäuble, on the first German Islam Conference, before the German Parliament, Berlin, September.

Schierup, C., P. Hansen and S. Castles (2006) Migration, Citizenship and the European Welfare State. Oxford: Oxford University Press.

Schild, J. (2003) 'Europäisierung nationaler politischer Identitäten in Deutschland und Frankreich: Politische Eliten, Parteien, Bürger' (Europeanization of national political identities in Germany and France: political elites, parties, citizens), Aus Politik und Zeitgeschichte 3-4: 31-9.

Schirrmacher, F. (2006) 'Alice Schwarzer im Interview: Die Islamisten meinen es so ernst wie Hitler' (Interview with Alice Schwarzer: The Islamists are as serious as Hitler), Frankfurter Allgemeine Zeitung, 4 July, p. 35

Spielhaus, R. (2006) 'Religion und Identität. Vom deutschen Versuch, "Ausländer" zu "Muslimen" zu machen' (Religion and identity. On the German attempt to turn 'aliens' into 'Muslims'), Internationale Politik 3: 28-36.

Terkessidis, M. and Y. Karakașoğlu (2006) 'Gerechtigkeit für die Muslime!' (Justice for the Muslims!), Die Zeit 6: 49.

Türkischer Bund in Berlin-Brandenburg (2005) '10-Punkte Plan des TBB zur Bekämpfung der Intoleranz gegenüber Frauen' (Ten-point plan of the TBB to fight intolerance towards women) [http://www.tbb-berlin.de/de/archiv/Zehnpun kteplan.php].

Unabhängige Kommission 'Zuwanderung' (2001) 'Zuwanderung gestalten Integration fördern. Bericht der Unabhängigen Kommission "Zuwanderung". Zusammenfassung' (Framing immigration - promoting integration: Report of the Independent 'Immigration' Commission. Summary) [http://www.dgb.de/ themen/migration/dokumente/kom_bericht_kurzf.pdf]

Volz, R. (2003) 'Zwangsheirat in Deutschland - eine tolerierte Menschenrechtsverletzung' (Forced marriage in Germany - a tolerated human rights' violation), Beiträge zur Feministischen Theorie und Praxis 63-4:199-202.

PETRA ROSTOCK is a Research Fellow in the Department of Political and Social Science at Free University Berlin. Address: Department of Political and Social Science, Otto Suhr Institute for Political Science, Free University Berlin, Ihnestr. 2214195 Berlin, Germany. [email: prostock@zedat.fu-berlin.de]

SABINE BERGHAHN is a Senior Researcher and Lecturer in the Department of Political and Social Science, Free University Berlin. Address: Department of Political and Social Science, Otto Suhr Institute for Political Science, Free University Berlin, Ihnestr. 2214195 Berlin. [email: berghahn@zedat.fu-berlin.de] 